\title{
Isolation and characterisation of an anticryptococcal protein in human cerebrospinal fluid
}

\author{
M. AHLUWALIA*, E. BRUMMER*†, S. SRIDHAR*, R SINGH* and D. A. STEVENS*† \\ * Division of Infectious Diseases, Department of Medicine, Santa Clara Valley Medical Center and California \\ Institute for Medical Research, San Jose, CA and †Stanford University School of Medicine, Stanford, CA, USA
}

\begin{abstract}
An earlier study reported that human cerebrospinal fluid (CSF) has fungistatic activity for Cryptococcus neoformans. The present study reports that molecular sieve fractionation of concentrated CSF yielded three protein peaks, one of which (p2) had anticryptococcal activity. On a DEAE-Sephacel anion-exchange column the active molecular sieve peak (p2) gave two peaks that contained anticryptococcal activity. The first (DEAE-1) eluted with $0.1 \mathrm{M} \mathrm{NaCl}$ and the second (DEAE-2) eluted with $0.2 \mathrm{M} \mathrm{NaCl}$ in buffer. Fungistatic activity of DEAE-1 was reversed by $\mathrm{FeCl}_{3}$. $\mathrm{Moreover} \mathrm{FeCl}_{3}$ reversed inhibition of $C$. neoformans growth by CSF. In contrast, activity of DEAE-2 was not reversed by $\mathrm{FeCl}_{3}$, indicating that inhibition was produced by an ironindependent mechanism. Immunoblot assays showed that transferrin was present in DEAE-1 but not in DEAE-2, whereas albumin was present in DEAE-2 but not in DEAE1. On NuPAGE, DEAE-1 protein migrated as a single band corresponding to transferrin and DEAE-2 protein gave a single band corresponding to albumin. In control experiments, human serum albumin subjected to the same isolation protocol acquired anticryptococcal activity similar to that of DEAE-2. Therefore, CSF albumin (DEAE-2) activity was associated with the isolation protocol. These data indicate that transferrin, present in or isolated from CSF, sequesters trace amounts of ferric iron, inhibits growth of $C$. neoformans and acts as an innate defence mechanism.
\end{abstract}

\section{Introduction}

Cryptococcal meningitis is the most serious form of cryptococcosis, mostly seen in immunocompromised patients, e.g., AIDS patients [1,2]. Although Cryptococcus neoformans can be isolated from cerebrospinal fluid (CSF) of patients with cryptococcal meningitis, little is known about factors affecting the growth of $C$. neoformans in this compartment. A previous study reported that a protein fraction from CSF inhibited the growth of $C$. neoformans in vitro, but the mechanism was not elucidated [3]. The present study used several sequential methods to further isolate and characterise the factor(s) in CSF responsible for anticryptococcal activity to identify natural resistance factors in CSF, and their mechanism of action, and understanding of

Received 24 Jan. 2000; revised version received 16 May 2000; accepted 20 May 2000.

Corresponding author: Dr D.A. Stevens, Dept. Med., Santa Clara Valley Med Ctr., 751 South Bascom Ave, San Jose, CA 95128-2699, USA. host resistance to $C$. neoformans in the central nervous compartment.

\begin{abstract}
Materials and methods
C. neoformans

A clinical isolate of $C$. neoformans (46545) was used in these studies. The isolate was grown at $35^{\circ} \mathrm{C}$ on Sabouraud dextrose agar for $24-48 \mathrm{~h}$. Yeast cells were collected, washed with saline and counted in a haemocytometer.
\end{abstract}

\section{Cerebrospinal fluid (CSF)}

CSF was collected from various sources, filter sterilised, tested to exclude antifungal drug activity and confirmed to have normal protein and glucose concentrations, as described previously [3].

CSF was tested for anticryptococcal activity by diluting it with an equal volume of double strength RPMI-1640 medium; the mixture is referred to hereafter as $50 \%$ 
CSF. Lower concentrations of CSF were made by adding sterile distilled water to CSF before dilution with an equal volume of double strength RPMI-1640.

\section{Assay system}

Sets of quadruplicate cultures were made in wells of micro-test plates (Costar \#3696; Corning, Inc., Corning, NY, USA). Suspensions of yeast cells in various test media were dispensed at $0.1 \mathrm{ml} /$ well. Cultures were incubated for $24 \mathrm{~h}$ at $37^{\circ} \mathrm{C}$ in air $95 \%+\mathrm{CO}_{2} 5 \%$. Cultures were harvested by aspiration into distilled water and culture wells were washed twice with distilled water. Dilutions of harvested material were plated on blood agar. Inoculated plates were incubated for $48 \mathrm{~h}$ at $35^{\circ} \mathrm{C}$, then colonies were counted. Percent fungistatis, or inhibition of growth, was calculated by the formula: [1 - (experimental cfu/control (RPMI1640) $\mathrm{cfu})] \times 100$.

\section{Iron}

Anhydrous ferric chloride $\left(\mathrm{FeCl}_{3}\right)$ was prepared just before each experiment in distilled water at $10 \mathrm{mM}$, diluted to $0.2 \mathrm{mM}$ and $0.01 \mathrm{ml}$ was delivered into each $0.1-\mathrm{ml}$ culture to give $20 \mu \mathrm{M}$.

\section{Molecular sieve fractionation}

Sephadex G-200 (Sigma) gel columns were prepared and equilibrated with phosphate-buffered saline (PBS) diluted 1 in 10 . The $\mathrm{G}-200$ columns $(2.5 \mathrm{~cm} \times 100 \mathrm{~cm})$ were calibrated with bovine serum albumin (BSA), hen egg albumin (OVA) and cytochrome $\mathrm{c}$ as mol. wt standards.

Pooled CSF was lyophilised and reconstituted with distilled water to a $10 \times$ concentration $(10 \times \mathrm{CSF})$. Approximately $4 \mathrm{ml}$ of $10 \times \mathrm{CSF}$ was loaded on to a Sephadex G-200 column and fractions were eluted with PBS dilution 1:10. Samples $(5 \mathrm{ml})$ were collected and protein concentrations were estimating by absorption at $280 \mathrm{~nm}$.

\section{Anion-exchange column fractionation}

DEAE (diethylaminoethyl)-Sephacel (Pharmacia LKB, Uppsala, Sweden) anion-exchange columns $(1.5 \times 5-$ $10 \mathrm{~cm}$ ) were prepared, equilibrated with Tris-HCl buffer $(0.1 \mathrm{M}, \mathrm{pH} 8.15)$ and calibrated by elution of a mixture of cytochrome c, BSA, OVA and human serum albumin (HSA; Sigma) with increasing concentrations of $\mathrm{NaCl}$ in Tris- $\mathrm{HCl}$ buffer.

After the sample had been dialysed against Tris- $\mathrm{HCl}$ buffer it was applied to the DEAE-Sephacel column, left to stand for 30-45 min, then step-wise elution was done with Tris- $\mathrm{HCl}$ buffer and $0.1 \mathrm{M}, 0.2 \mathrm{M}$ and $0.3 \mathrm{M}$ $\mathrm{NaCl}$ in Tris- $\mathrm{HCl}$ buffer. An elution profile of proteins from the DEAE Sephacel column was determined by absorbance at $280 \mathrm{~nm}$.

\section{Dye affinity columns}

In other experiments, a dye affinity column, Blue 72, which binds human albumin (Sigma) was used to study DEAE-2 proteins. Columns were equilibrated with $20 \mathrm{ml}$ buffer $(0.01 \mathrm{M}$ Tris-HCl, $\mathrm{pH} 7.5)$ and DEAE-2 was applied to the dye affinity columns. Elution of protein from the column with buffer gave unbound fractions and elution with buffer $+1.5 \mathrm{M} \mathrm{NaCl}$ yielded bound fractions.

\section{Immuno-dot-blot assay}

To verify the presence of certain proteins in active fractions from the DEAE-Sephacel anion-exchange column, an Immuno-Blot protein $G$ horseradish peroxidase assay kit (Sigma) was used. Sheep anti-human albumin IgG (Biodesign, Kennebunk, ME, USA) and rabbit anti-human transferrin immunoglobulin (Dako, Santa Barbara, CA, USA) were used in the assay.

\section{NuPAGE electrophoresis}

NuPAGE pre-cast Bis-Tris polyacrylamide mini-gel electrophoresis system (Novex, San Diego, CA, USA) was run in a neutral ( $\mathrm{pH}$ 7.0) environment. Nonreduced samples were electrophoresed on NuPAGE $10 \%$ or Bis-Tris $4-12 \%$ gels with a $3-(\mathrm{N}-$ morpholino) propane sulphonic acid-SDS running buffer in the Novex Xcell-II apparatus. Pre-cast gels, sample and running buffers were purchased from Novex. Proteins in gels were fixed, stained with Coomassie Blue, and de-stained according to standard methods. Stained gels were photographed with a digital camera (Bio-Image, Ann Arbor, MI, USA); digital images were stored by a Dell P100t computer (Dell, Austin, TX, USA) and printed with a digital graphic printer (Sony UP-D860, Sunnyvale, CA, USA).

\section{Iso-electric focusing (IEF)}

Novex IEF gels, non-denaturing (no urea), containing polyacrylamide $5 \%$, were used for $\mathrm{pI}$ determination and confirmation of isoforms of purified products. Electrophoresis was done according to the manufacturer's instructions with buffers purchased from Novex. The $\mathrm{pH} \mathrm{3-7} \mathrm{gels} \mathrm{were} \mathrm{used} \mathrm{for} \mathrm{a} \mathrm{pI} \mathrm{performance} \mathrm{range} \mathrm{of}$ 3.0-7.0. The IEF gels were stained by the Coomassie Blue method, photographed and analysed as described above.

\section{Statistical analysis}

The data were analysed for statistical significance by Student's $t$ test. Statistical significance was set at $\mathrm{p}<0.05$. The GB-Stat program (Microsoft, Redmond, WA, USA) for Bonferroni's adjustment to the $t$ test was 
used for multiple comparisons against a single control group.

\section{Results}

\section{Anticryptococcal activity of CSF}

Previously, 50\% CSF from several individual sources significantly $(\mathrm{p}<0.01)$ inhibited the growth of $C$. neoformans strain CDC 9759, 86(SD 12)\%, $\mathrm{n}=10$ [3]. As all individual CSF samples had anticryptococcal activity, CSFs were pooled, concentrated and used for fractionation and purification studies.

\section{Molecular sieve fractionation of CSF}

Fractionation of $4 \mathrm{ml}$ of $10 \times \mathrm{CSF}$ with a Sephadex G-200 column produced a protein elution profile consisting of three major peaks (Fig. 1). The same profile was obtained in four different fractionation runs of $10 \times \mathrm{CSF}$. Fractions making up the first peak (P1), the second peak (P2) and the third peak (P3) were separately pooled. Pooled fractions were lyophilised, dialysed against distilled water, sterilised by filtration and tested for anticryptococcal activity. Significant $(\mathrm{p}<0.01)$ anticryptococcal activity was found only in P2 (Fig. 1). In testing P2 proteins from three different fractionations of CSF on Sephadex G-200, $250 \mu \mathrm{g} / \mathrm{ml}$ caused 79 (SD 4)\% inhibition of C. neoformans growth. Anticryptococcal activity in P2 (88\%) was completely abolished by heating at $80^{\circ} \mathrm{C}$ for $60 \mathrm{~min}$.

\section{Anion-exchange chromatography}

Proteins in P2 from fractionation of CSF on a Sephadex G-200 column were separated further on a DEAESephacel anion-exchange column; $3 \mathrm{ml}$ of P2 (4.5 mg of protein $/ \mathrm{ml})$ were applied to a $(1.5 \times 10)$-cm DEAESephacel column and sequentially eluted as described earlier. The protein elution profile is shown in Fig. 2. An almost identical profile was obtained when another 3-ml sample of P2 was run on DEAE-Sephacel.

DEAE-Sephacel fractions in peaks DEAE-1 and DEAE-2 (Fig. 2) were pooled, lyophilised, dialysed against distilled water, sterilised by filtration and tested for anticryptococcal activity. The results are shown in Table 1. Both peaks contained proteins which significantly $(\mathrm{p}<0.01)$ inhibited growth of $C$. neoformans (67\% and 56\%, respectively) (Table 1). Similar results were obtained when DEAE-1 and DEAE-2 from fractionation of another pool of CSF was tested, e.g., DEAE-1 inhibited $C$. neoformans by 75 (SD 4)\% and DEAE-2 by $92(\mathrm{SD} 2) \%$ at $250 \mu \mathrm{g} / \mathrm{ml}(\mathrm{n}=2)$.

When two-fold concentrations of DEAE-1 were tested for inhibitory activity against $C$. neoformans, inhibition was constant from $250 \mu \mathrm{g} / \mathrm{ml}$ to $32 \mu \mathrm{g} / \mathrm{ml}(68-65 \%)$ but at $16 \mu \mathrm{g} / \mathrm{ml}$ it was $37 \%$, and $0 \%$ at $8 \mu \mathrm{g} / \mathrm{ml}$. In contrast, the inhibitory activity of DEAE-2 was concentration-dependent, e.g., $98 \%$ at $500 \mu \mathrm{g} / \mathrm{ml}$, $75 \%$ at $250 \mu \mathrm{g} / \mathrm{ml}, 46 \%$ at $125 \mu \mathrm{g} / \mathrm{ml}, 33 \%$ at $62.5 \mu \mathrm{g} / \mathrm{ml}, 4 \%$ at $31.25 \mu \mathrm{g} / \mathrm{ml}$.

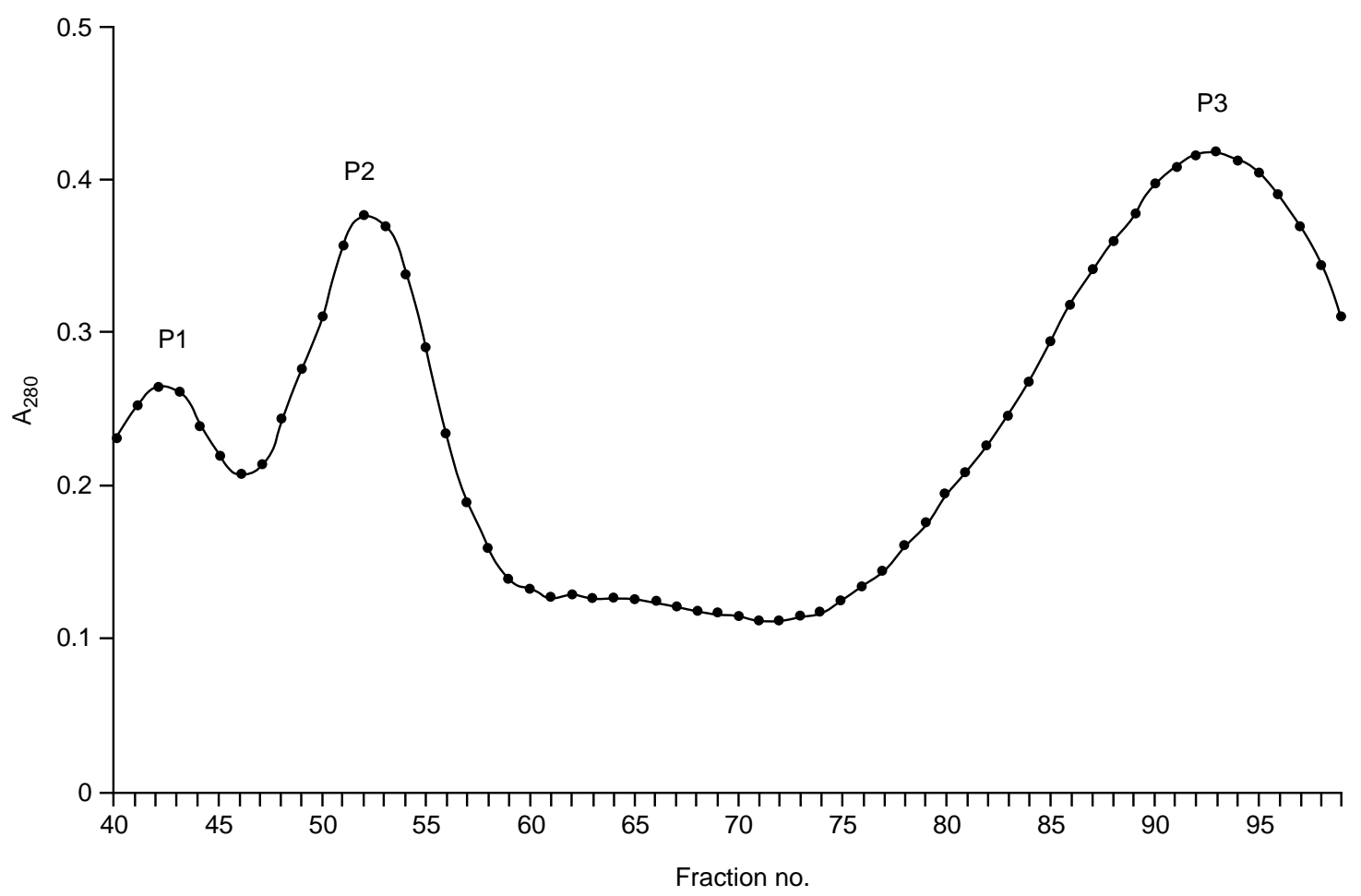

Fig. 1. Fractionation of CSF on Sephadex G-200: $4 \mathrm{ml}$ of $10 \times \mathrm{CSF}$ were applied to the Sephadex G-200 column and 5$\mathrm{ml}$ fractions were eluted with PBS 1 in 10 . Protein concentrations of samples were estimated by absorption at $280 \mathrm{~nm}$ and are shown on the vertical axis. P, peak. 


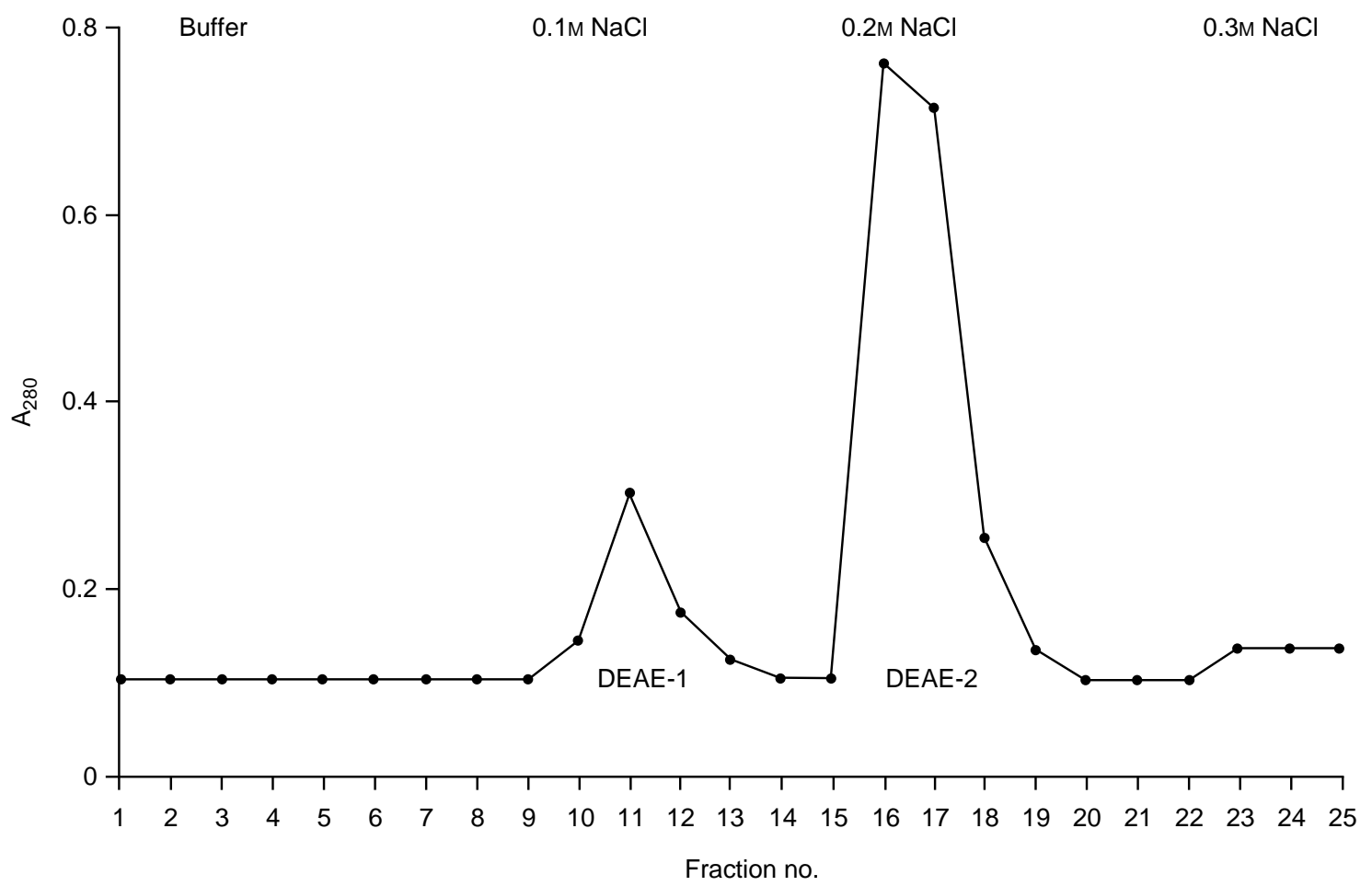

Fig. 2. Anion-exchange fractionation of peak 2 from the Sephadex G-200 column: $3 \mathrm{ml}$ of G-200 fraction 2 (4.5 mg of protein $/ \mathrm{ml}$ ) were loaded on to the DEAE-Sephacel column and the column was sequentially eluted with Tris- $\mathrm{HCl}$ buffer, $0.1 \mathrm{M}, 0.2 \mathrm{M}$ and $0.3 \mathrm{M} \mathrm{NaCl}$ in buffer. Protein concentrations in the $5-\mathrm{ml}$ fractions are indicated by absorbance at $280 \mathrm{~nm}$ on the vertical axis. Peaks are denoted by DEAE-1 and DEAE-2.

Table 1. Anticryptococcal activity of DEAE-1 and DEAE-2 proteins

\begin{tabular}{lcc}
\hline Preparation* & $\begin{array}{c}\text { Mean (SD) viable count of } \\
\text { C. } \text { neoformans }(\mathrm{cfu})\end{array}$ & $\begin{array}{c}\text { Inhibition } \\
(\%)\end{array}$ \\
\hline Inoculum & $890(65)$ & $\ldots$ \\
RPMI-1640 & $53750(3000)$ & 0 \\
$50 \%$ CSF & $15200(400)$ & 72 \\
DEAE-1 & $18200(1500)$ & 67 \\
DEAE-2 & $24000(2000)$ & 56 \\
\hline
\end{tabular}

Data are from quadruplicate cultures per experiment.

${ }^{*}$ See Methods. DEAE-1 and DEAE-2 were tested at $250 \mu \mathrm{g} / \mathrm{ml}$

\section{Immuno-dot-blot assay}

An immunoblot assay was used to verify the presence of certain proteins in DEAE-1 and DEAE-2. With rabbit anti-human transferrin IgG in the assay, DEAE1, transferrin control and CSF gave a positive reaction, whereas DEAE-2 was negative. When sheep antihuman albumin immunoglobulin was used in the assay, DEAE-2 and the albumin control gave strongly positive results, whereas DEAE-1 and transferrin gave faint results. These data confirm the presence of transferrin in DEAE-1 but not in DEAE-2. Conversely, albumin appeared to be present in DEAE-2 but not DEAE-1.

\section{NuPAGE electrophoresis}

To further identify and characterise proteins in DEAE1 and DEAE-2 they were electrophoresed on NuPAGE. Protein in DEAE-2 migrated as a single band and was identical in migration to purified HSA, $69 \mathrm{kDa}$ (Fig. 3). The major protein in DEAE-1 migrated to the same

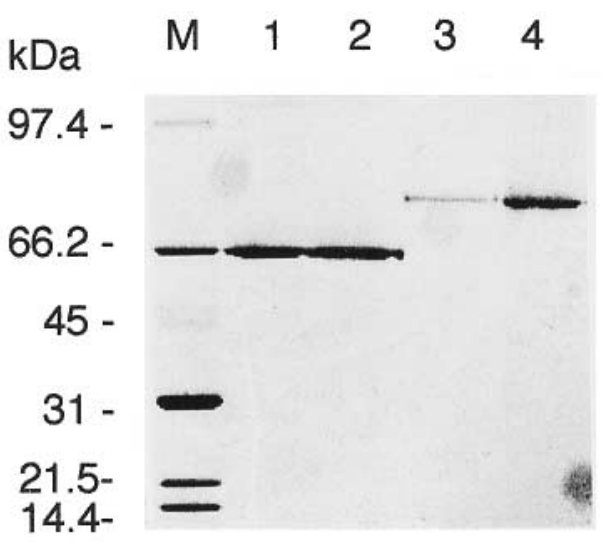

Fig. 3. NuPAGE electrophoresis. DEAE-1 and DEAE-2 proteins were electrophoresed on NuPAGE $4-12 \%$ gels. Lane M, mol. wt markers; 1, serum albumin; 2, DEAE-2; 3, DEAE-1; 4, transferrin.

position as human transferrin, $81 \mathrm{kDA}$ (Fig. 3). These results are in agreement with immunoblot results and 
confirm that DEAE-1 and DEAE-2 consist primarily of transferrin and albumin, respectively.

\section{Effect of exogenous iron}

Proteins in DEAE-1 $(125 \mu \mathrm{g} / \mathrm{ml})$ inhibited growth of C. neoformans by $77 \%(\mathrm{p}<0.01)$. This was completely reversed by $20 \mu \mathrm{M} \mathrm{FeCl}_{3}$ (Table 2). Similar results were obtained in a second test of DEAE-1. Moreover, inhibition of growth of $C$. neoformans by CSF (87\%, $\mathrm{p}<0.01$ ) was completely reversed by $\mathrm{FeCl}_{3}$ (Table 2). In other tests, CSF inhibition of $C$. neoformans growth $(91 \mathrm{SD} 5 \%, \mathrm{n}=3$ ) was reduced to $3(\mathrm{SD} 5) \%$ by $20 \mu \mathrm{M} \mathrm{FeCl}{ }_{3}$. In contrast, inhibition of $C$. neoformans growth (94 SD3\%) by proteins in DEAE-2 $(250 \mu \mathrm{g} / \mathrm{ml})$ was not reversed by $20 \mu \mathrm{M} \mathrm{FeCl}_{3}$ (results not shown). This indicated that DEAE-2 proteins exerted inhibitory activity against $C$. neoformans by some mechanism other than iron deprivation.

\section{Comparison of CSF with transferrin}

Iron-free transferrin (apotransferrin, Sigma) inhibited the growth of $C$. neoformans in RPMI-1640. The inhibition curve of transferrin was flat over two-fold dilutions from $50 \mu \mathrm{g} / \mathrm{ml}(79 \%)$ to $12.5 \mu \mathrm{g} / \mathrm{ml}(72 \%)$ and at $6.25 \mu \mathrm{g} / \mathrm{ml}$ dropped to $60 \%$. $\mathrm{FeCl}_{3}$, even at $5 \mu \mathrm{M}$, reversed inhibition of $C$. neoformans growth by all concentrations of transferrin.

When 50\% CSF was compared with transferrin at $12.5 \mu \mathrm{g} / \mathrm{ml}$, they had similar inhibitory activity, $73 \%$ and $72 \%$, respectively (Table 3$). \mathrm{FeCl}_{3}(5 \mu \mathrm{M})$, not only reversed the inhibitory activity of CSF and transferrin, but significantly $(\mathrm{p}<0.01)$ enhanced growth of $C$. neoformans over growth in RPMI-1640 alone.

\section{IEF chromatography}

IEF chromatography showed that commercial (99\% purified) HSA differed slightly from DEAE-2 protein (Fig. 4, lane 3 versus lane 4). HSA had a slightly lower pI than DEAE-2 protein. Moreover, DEAE-2 protein that was bound (then eluted) or unbound by a Blue 72

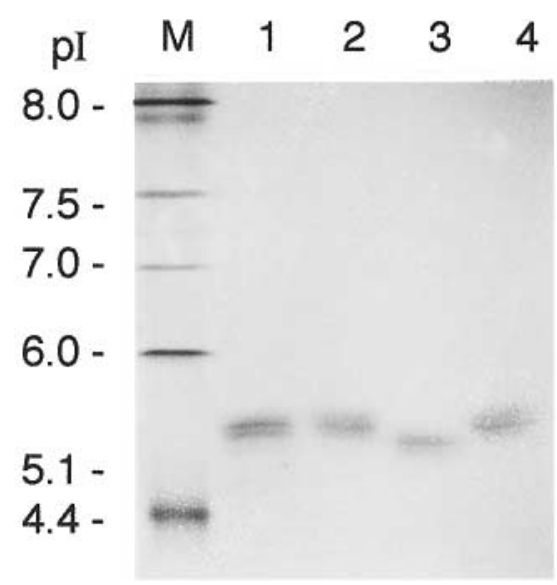

Fig. 4. Iso-electric focusing (IEF). DEAE-2 protein bound and unbound to Blue 72 dye affinity columns, as well as DEAE-2, were electrophoresed on Novex IEF gels (5\% PAGE) with a pI 3.0-7.0 range. Lane $\mathbf{M}$, migration pI markers; 1, unbound Blue 72 proteins; 2, bound Blue 72 proteins; 3, human serum albumin; 4 , unfractionated DEAE-2 proteins.

Table 2. Reversal of CSF or DEAE-1 growth inhibition with exogenous iron

\begin{tabular}{lccc}
\hline Preparation* & $\begin{array}{c}\text { Mean (SD) viable count of } \\
\text { C. neoformans }(\mathrm{cfu})\end{array}$ & $\begin{array}{c}\text { Inhibition } \\
(\%)\end{array}$ & $\begin{array}{c}\text { n-Fold } \\
\text { enhancement } \\
\text { of growth }\end{array}$ \\
\hline Inoculum & $977(66)$ & $\ldots$ & $\ldots$ \\
RPMI-1640 & $93000(17000)$ & $\ldots$ & $\ldots$ \\
$\quad+\mathrm{FeCl}_{3}$ & $187000(25000)$ & 0 & 2.0 \\
$\mathrm{DEAE}-1$ & $22250(2500)$ & 77 & 2.2 \\
$\quad+\mathrm{FeCl}_{3}$ & $206000(16000)$ & 0 & 1.5 \\
$50 \% \mathrm{CSF}^{+}$ & $12400(1600)$ & 87 & \\
$+\mathrm{FeCl}_{3}$ & $139000(22000)$ & 0 & \\
\hline
\end{tabular}

Data are from quadruplicate cultures per experiment.

Fold enhancement, or inhibition, refers to comparison of cfu in experimental cultures to growth in RPMI-1640.

${ }^{*}$ See Methods. $\mathrm{FeCl}_{3}$ tested at $20 \mu \mathrm{M}$, DEAE-1 at $125 \mu \mathrm{g} / \mathrm{ml}$.

Table 3. Comparison of effect of CSF and transferrin on growth of C. neoformans

\begin{tabular}{lccc}
\hline & $\begin{array}{c}\text { Mean (SD) viable count of } \\
\text { C. neoformans (cfu) }\end{array}$ & $\begin{array}{c}\text { Inhibition } \\
(\%)\end{array}$ & $\begin{array}{c}\text { n-Fold } \\
\text { enhancement } \\
\text { of growth }\end{array}$ \\
\hline Preparation* & $1630(120)$ & $\ldots$ & $\ldots$ \\
RPMI-1640 & $110000(15000)$ & $\ldots$ & $\ldots$ \\
$\quad+\mathrm{FeCl}_{3}$ & $250000(40000)$ & 73 & 2.2 \\
$\mathrm{CSF}(50 \%)$ & $30000(2500)$ & 0 & 2.0 \\
$+\mathrm{FeCl}_{3}$ & $225000(45000)$ & 72 & 2.0 \\
$\mathrm{Transfrin}^{+}$ & $31000(3000)$ & 0 & \\
$+\mathrm{FeCl}_{3}$ & $230000(10000)$ & & \\
\hline
\end{tabular}

Data are from quadruplicate 24-h cultures per experiment.

* See Methods. $\mathrm{FeCl}_{3}$ tested at $5 \mu \mathrm{M}$, transferrin at $12.5 \mu \mathrm{g} / \mathrm{ml}$. 
column also had a slightly higher pI than HSA (Fig. 4, lanes 1 and 2 versus 3 ).

\section{Comparison of HSA with DEAE-2}

The anticryptococcal activity of albumin-like protein isolated from CSF as DEAE-2 was intriguing, because HSA did not inhibit growth of $C$. neoformans in earlier studies [4]. To determine if DEAE-2 from CSF was different from HSA, a mixture of HSA and human transferrin was chromatographed on Sephadex G-200. The G-200 peak with anticryptococcal activity was lyophilised, dialysed, sterilised and chromatographed on a DEAE-Sephacel column. The peak eluted with $0.1 \mathrm{M}$ $\mathrm{NaCl}$ in buffer had activity similar to commercial transferrin and activity was reversed by $20 \mu \mathrm{M} \mathrm{FeCl}{ }_{3}$. The peak eluted with $0.2 \mathrm{M} \mathrm{NaCl}$ in buffer was lyophilised, dialysed, sterilised and tested for inhibition of growth of $C$. neoformans. HSA isolated under these conditions inhibited the growth of $C$. neoformans by $98 \% \quad(400 \mu \mathrm{g} / \mathrm{ml}), 44 \% \quad(200 \mu \mathrm{g} / \mathrm{ml})$ and $0 \%$ $(100 \mu \mathrm{g} / \mathrm{ml})$. In contrast, commercial HSA enhanced the growth of $\mathrm{CN}$ by three-to-four fold at these concentrations.

Moreover, it was observed that DEAE-2 protein with anticryptococcal activity lost activity when stored at $4^{\circ} \mathrm{C}$. For example, DEAE-2 activity decreased inhibition of $C$. neoformans growth from $94 \%$ to $42 \%$ after 4 weeks at $4^{\circ} \mathrm{C}$. In contrast, DEAE-1 protein lost little of its activity, decreasing from 76 (SD 2)\% to 66 (SD 7)\% inhibition of $C$. neoformans growth $(\mathrm{n}=2)$ under the same conditions. HSA chromatographed on DEAESephacel and eluted lost activity at $4^{\circ} \mathrm{C}$ as did DEAE2. Moreover, both also lost activity when frozen and thawed five times.

With IEF chromatography, the HSA isolated under the conditions described above was shown to have a slightly higher $\mathrm{pI}$ than unmanipulated HSA. Thus, it is concluded that the anticryptococcal activity of DEAE-2 protein (albumin) from CSF resulted from the isolation procedure.

\section{Discussion}

This study has extended previous work [3] showing that CSF and CSF proteins isolated by molecular sieve chromatography significantly inhibit the growth of $C$. neoformans compared with growth in tissue culture medium alone. Further separation of CSF proteins by anion-exchange chromatography yielded two apparently pure sets of proteins that inhibited growth of $C$. neoformans. The activity-dilution curve with DEAE-1 (16 $\mu \mathrm{g} / \mathrm{ml}$ yielded $37 \%$ inhibition) suggests that, as CSF protein $95 \mu \mathrm{g} / \mathrm{ml}$ gave $43 \%$ inhibition [3], the sequential Sephadex G-200 and DEAE-Sephacel chromatographic procedures resulted in enrichment of activity by $c$. six-fold in the DEAE-1 fraction.
The primary protein in DEAE-1 was transferrin and it had anticryptococcal activity in this system. The presence of transferrin (DEAE-1) in CSF, and reversibility of inhibition by $\mathrm{FeCl}_{3}$, explain the anticryptococcal activity of CSF. The inhibition demonstrated by pure transferrin suggests that it could account for all the inhibition by CSF; 50\% CSF and transferrin $12.5 \mu \mathrm{g} / \mathrm{ml}$ resulted in $72-73 \%$ inhibition (Table 3) and this activity of transferrin is consistent with its concentration in normal CSF $50 \%$ CSF would contain c. $7 \mu \mathrm{g} / \mathrm{ml}$ [5]. DEAE-1 protein in NuPAGE electrophoresis migrated to the same point as purified transferrin, although CSF inhibitory material isolated from Sephadex G-200 and electrophoresed in SDSpolyacrylamide gel had previously suggested a lower mol. wt for the inhibitory material [3]. The latter set of procedures did not separate molecules in the 66$81 \mathrm{kDa}$ range effectively, whereas the set of procedures used in the present study separated HSA and transferrin following the anion-exchange step.

Transferrin in the CSF may be derived by passage from the brain interstitium of transferrin synthesised by oligodendrocytes or the small amount of transferrin (synthesised in the liver) transported through the blood-brain barrier, by secretion of choroid plexus epithelial cells directly into ventricles, or by trancytosis of liver-derived transferrin from blood through the choroid plexuses into the ventricles [6]. The present studies add another potential function, that of antimicrobial activity, to the putative functions of CSF transferrin: i.e., neutralisation of the toxic effects of unbound iron, transport of iron to brain cells and export of iron from the brain during re-absorption of CSF into the blood [6].

Iron acquisition by $C$. neoformans has been elucidated recently $[7,8]$. C. neoformans can use ferric iron by a ferric iron reductase pathway in concert with a high affinity ferrous iron transporter [8]. However, in man, ferric iron is not available to $C$. neoformans because it is sequestered by transferrin in the serum, or as shown here, by transferrin in CSF. Consequently, iron overload in man presents a risk factor for C. neoformans infection.

Ferrous iron can be utilised directly by $C$. neoformans by way of a low affinity transporter. This transport system in C. neoformans is thought to be the same as that found in Saccharomyces cerevisiae [9]. However, the presence of ferrous iron in man is fleeting, because it is changed to ferric iron by ceruloplasmin present in serum and CSF, and ferric iron is sequestered by transferrin. This observation emphasises the important role of ceruloplasmin in nutritional immunity [10].

The present study found that the albumin fraction from CSF (DEAE-2) had anticryptococcal activity, and this was a puzzling result. However, control experiments with HSA indicated that the anticryptococcal activity 
of albumin isolated from CSF was due to changes induced by the isolation procedure.

In summary, it has been shown that CSF inhibits growth of $C$. neoformans by ferric iron deprivation and is an example of nutritional immunity operating in the central nervous system against $C$. neoformans. Iron overload could be risk factor for $C$. neoformans infection in the central nervous system.

\section{References}

1. Eng RH, Bishburg E, Smith CM, Kapila R. Cryptococcal infections in patients with acquired immune deficiency syndrome. Am J Med 1986; 81: 19-23.

2. Sugar AM. Overview: cryptococcosis in the patient with AIDS. Mycopathologia 1991; 114: 153-157.

3. Brummer E, Drasin T, Adler JD, Stevens DA. Antifungal activity of cerebrospinal fluid against Cryptococcus neoformans and Candida species. Med Mycol 1999; 37: 339-344.

4. Nassar F, Brummer E, Stevens DA. Different components in human serum inhibit multiplication of Cryptococcus neoformans and enhance fluconazole activity. Antimicrob Agents Chemother 1995; 39: 2490-2493.

5. Fishman RA. Cerebrospinal fluid in diseases of the nervous system, 2nd edn. Philadelphia; WB Saunders. 1992.

6. Moos T, Morgan EH. Brain iron homeostasis. In: Paulson D, Knudsen GM, Moos T (eds) Brain barrier systems. Copenhagen, Munksgaard, 1999.

7. Nyhus KJ, Wilborn AT, Jacobson ES. Ferric iron reduction by Cryptococcus neoformans. Infect Immun 1997; 65: 434-438.

8. Jacobson ES, Goodner AP, Nyhus KJ. Ferrous iron uptake in Cryptococcus neoformans. Infect Immun 1998; 66: 4169-4175.

9. Askwith CC, de Silva D, Kaplan J. Molecular biology of iron acquisition in Saccharomyces cerevisiae. Mol Microbiol 1996; 20: $27-34$.

10. Yoshida K, Furihata K, Takeda $\mathrm{S}$ et al. A mutation in ceruloplasmin gene is associated with systemic hemosiderosis in humans. Nature Genet 1995; 9: 267-272. 